\section{Lead and Arsenic in Two Apricot Cultivars and in 'Gala' Apples Grown on Lead Arsenate-contaminated Soils}

\author{
Timothy L. Creger ${ }^{1}$ and Frank J. Peryea \\ Tree Fruit Research and Extension Center, Washington State University, \\ 1100 North Western Avenue, Wenatchee, WA 98801
}

Additional index words. Prunus armeniaca, Malus domestica, heavy metal, pesticide, food safety

\begin{abstract}
Concerns about food safety prompted a case study of the arsenic and $\mathrm{Pb}$ contents of tree fruits grown on lead arsenate-contaminated soil. The arsenic concentration in apricot (Prunus armeniaca L.) and 'Gala' apple (Malus domestica Borkh.) fruit was positively related to concentrated HCl-extractable soil arsenic. Fruit arsenic in both species did not exceed $70 \mu \mathrm{g} \cdot \mathrm{kg}^{-1}$ fresh weight (fw). Fruit $\mathrm{Pb}$ was below the limits of detection of $20 \mu \mathrm{g} \cdot \mathrm{kg}^{-1} \mathrm{fw}$ for apricot and $24 \mu \mathrm{g} \cdot \mathrm{kg}^{-1}$ fw for apple. All of these concentrations are substantially below levels associated with human health risk. 'Riland' apricot trees did not show arsenic phytotoxicity at soil, fruit, and leaf arsenic concentrations associated with phytotoxicity symptoms in 'Goldrich' apricots. The apple trees showed no visual symptoms of arsenic phytotoxicity.
\end{abstract}

Lead arsenate compounds were the preferred pesticides for insect control in deciduous fruit trees before the introduction of synthetic organic pesticides in the late 1940s. Frequent application at high rates led to significant $\mathrm{Pb}$ and arsenic accumulation in orchard topsoils, particularly in apple orchards, throughout the world (Peryea, 1991a). Lead arsenate use as a pesticide for deciduous tree fruits in the United States was effectively eliminated during the late 1960s because of voluntary cancellation of registration and was officially banned in 1988 [U.S. Environmental Protection Agency (EPA), 1991a]. Although $\mathrm{Pb}$ and arsenic concentrations in tree fruits grown on lead arsenate-contaminated soils were elevated relative to those in fruits grown on uncontaminated soil (Jones and Hatch, 1937; MacLean and Langille, 1981), they were still considerably less than the tolerances of $7000 \mu \mathrm{g} \mathrm{Pb} / \mathrm{kg}$ fresh weight (fw) and $2650 \mu \mathrm{g}$ arsenic/kg fw used for raw agricultural commodities by the U.S. Food and Drug Administration (FDA) since the 1940s. An exception was reported by Veneman (1985), who found excessive $\mathrm{Pb}$ concentrations in the core tissue of some apples grown on lead arsenate-contaminated soils in Massachusetts. The FDA tolerances for $\mathrm{Pb}$ and arsenic in raw agricultural commodities were revoked by the EPA (1991a, 1991b),

Received for publication 10 Feb. 1992. Accepted for publication 8 July 1992. Department of Horticulture and Landscape Architecture Paper no. 9135, College of Agriculture and Home Economics Agricultural Research Center, Washington State Univ., Pullman. We thank R. Kammereck and M. Dilley for their technical support. The cost of publishing this paper was defrayed in part by the payment of page charges. Under postal regulations, this paper therefore must be hereby marked $a d$ vertisement solely to indicate this fact.

'Present address: Washington State Dept. of Agriculture, 406 General Administration Building, Olympia, WA 98504-2589. using an argument that tolerances are not required because all food use registrations of lead arsenate have been cancelled. In spite of this regulatory action, minimizing dietary intake of $\mathrm{Pb}$ and arsenic by humans is a recommended health policy (Hutton, 1987). Because $\mathrm{Pb}$ and arsenic concentrations in Washington-grown tree fruits have not been examined since lead arsenate use was effectively abandoned there in 1948 (Peryea, 1991a), we conducted a case study to determine the $\mathrm{Pb}$ and arsenic concentrations in the fruits of two tree fruit species grown on soils heavily contaminated with lead arsenate residues and to relate these concentrations to the commercially used soil test index for arsenic (Dow et al., 1983).

On 12 July 1988, fruits at commercial maturity were sampled from an apricot orchard planted in Spring 1984 on a lead arsenatecontaminated Burch loam soil (coarse-loamy, mixed, mesic Aridic Haploxeroll). All trees were on apricot seedling rootstock and were planted on a $6 \times 6-\mathrm{m}$ spacing. Two fruits (mean fresh mass $=106 \mathrm{~g} /$ fruit) were sampled from each of six 'Goldrich' trees showing no symptoms of arsenic phytotoxicity and severe arsenic phytotoxicity symptoms. Arsenic phytotoxicity symptoms included formation of small, circular, reddish lesions on the leaf blades, particularly along the vascular network, and, as the growing season progressed, leaf chlorosis, necrosis of the lesions, and tree defoliation (Benson et al., 1972). The fruit from the two symptomatic classes of 'Goldrich' trees did not differ visually. Ten leaves were randomly sampled from each of three 'Goldrich' trees with and three 'Goldrich' trees without arsenic phytotoxicity symptoms. Symptoms were absent on all 'Riland' pollinizer trees interplanted in the orchard. Five fruits (mean fresh mass $=64 \mathrm{~g} /$ fruit) and 10 leaves were randomly sampled from each of four 'Riland' trees. from each of six 'Goldrich' trees showing
The fruits were washed with distilled water, pits were removed, and the flesh was composited by tree, freeze-dried, ground in an agate mortar, and analyzed for total $\mathrm{Pb}$ and arsenic. The leaf samples were composited by cultivar and arsenic phytotoxicity symptoms, washed with distilled water, oven-dried at $85 \mathrm{C}$, ground in an agate mortar, and analyzed for total arsenic.

On 31 Aug. 1989, fruits at commercial maturity were sampled from an adjacent 'Gala'/EMLA 7 apple orchard planted in Spring 1987 on a lead arsenate-contaminated Burch loam soil. Four fruits (mean fresh mass $=230 \mathrm{~g} /$ fruit) were sampled from each of six trees trained using a central leader system $(2.5 \times 5-\mathrm{m}$ spacing $)$ and from each of eight trees trained using a French vertical-axis system $(1.75 \times 4.5-\mathrm{m}$ spacing $)$. The trees showed no visual signs of arsenic phytotoxicity. Each fruit sample was washed with distilled water, cut longitudinally into quarters, and seeds and stems were removed. Two opposing quarters were freeze-dried, ground in an agate mortar, and analyzed for total $\mathrm{Pb}$ and arsenic.

At both study sites, soil cores (0- to 50$\mathrm{cm}$ depth) were collected at four locations 1 $m$ from the base of each sampled tree (on opposite sides in-row and perpendicular to the tree row) and composited by tree. The soil samples were air-dried, gently crushed, and analyzed for $\mathrm{Pb}$ and arsenic.

Fruit $\mathrm{Pb}$ concentrations were measured by dry-ashing subsamples at $525 \mathrm{C}$, dissolving the ash in concentrated $\mathrm{HCl}$, and analyzing the digests for total $\mathrm{Pb}$ by flame atomic absorption spectrophotometry (AAS). Fruit arsenic was measured by neutron activation

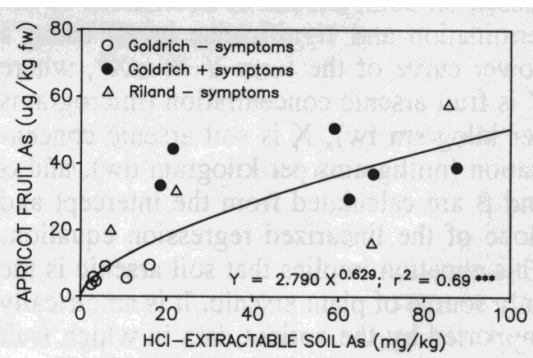

Fig. 1. Arsenic concentrations in 'Goldrich' and 'Riland' apricot fruits from trees with and without arsenic phytotoxicity symptoms as a function of $\mathrm{HCl}$-extractable soil arsenic ${ }^{* * *}$ significant at $\left.P=0.001\right)$.

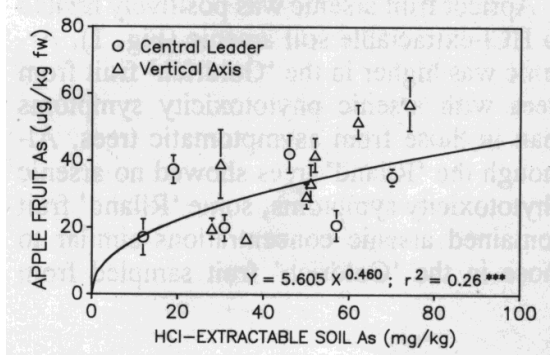

Fig. 2. Arsenic concentrations in 'Gala' apple fruits from trees of two training systems as a function of $\mathrm{HCl}$-extractable soil arsenic (***significant at $P=0.001$ ). Error bars indicate $95 \%$ confidence interval for mean values. 
analysis at the Washington State Univ. Nuclear Radiation Center. The soil samples were reacted in a 1 soil : 5 concentrated $\mathrm{HCl}$ suspension at room temperature for $1 \mathrm{~h}$. The supernatant was isolated by filtration through Whatman No. 42 filter paper and analyzed for $\mathrm{Pb}$ by flame AAS and for arsenic by a modified silver diethyldithiocarbamate method (Peryea, 1991b). This extraction method was cited by Benson (1976) as a measure of total soil arsenic; however, the efficiency of extraction varies with recovery ranging between $80 \%$ and $90 \%$ of total arsenic in lead arsenate-contaminated soils (F.J.P., unpublished data). Concentrated $\mathrm{HCl}$-extractable soil arsenic was as good a predictor of apple tree growth responses as other soil arsenic indices (Benson, 1976) and is used as the soil arsenic test procedure for Washington orchards (Benson et al., 1978; Dow et al., 1983). The $\mathrm{HCl}$ method extracts $>95 \%$ of total soil $\mathrm{Pb}$ in lead arsenate-contaminated soils (Veneman et al., 1982; F.J.P., unpublished data). All analyses were validated using appropriate reference standards. Fruit concentrations are reported on a fw basis; leaf and soil concentrations are dry-weight (dw) basis.

The relationships between the plant and soil content at sublethal levels of nonessential but potentially phytotoxic elements such as arsenic and $\mathrm{Pb}$ can be generally described by curvilinear functions that increase monotonically at a decreasing rate (e.g., Rolfe, 1973; Woolson, 1973). In the current study, the relationship between fruit arsenic and soil arsenic concentration was quantified using linear and nonlinear regression analysis (Weisberg, 1985). The data were best fit (based on comparisons of coefficient of determination and significance level) using a power curve of the form $Y=\alpha X^{\beta}$, where $\mathrm{Y}$ is fruit arsenic concentration (micrograms per kilogram $\mathrm{fw}$ ), $\mathrm{X}$ is soil arsenic concentration (milligrams per kilogram $\mathrm{dw}$ ), and $\alpha$ and $\beta$ are calculated from the intercept and slope of the linearized regression equation. This equation implies that soil arsenic is the only source of plant arsenic. It is empirically supported by the apricot data in which fruit arsenic approaches zero as soil arsenic approaches zero, The influence of tree training system on 'Gala' apple fruit arsenic was determined by using analysis of covariance to test for homogeneity of regression equation slopes (Weisberg, 1985).

Apricot fruit arsenic was positively related to $\mathrm{HCl}$-extractable soil arsenic (Fig. 1). Arsenic was higher in the 'Goldrich' fruit from trees with arsenic phytotoxicity symptoms than in those from asymptomatic trees. Although the 'Riland' trees showed no arsenic phytotoxicity symptoms, some 'Riland' fruit contained arsenic concentrations similar to those in the 'Goldrich' fruit sampled from trees with arsenic phytotoxicity symptoms. The highest fruit arsenic concentration was $56 \mu \mathrm{g} \cdot \mathrm{kg}^{-1} \mathrm{fw}(2.1 \%$ of the former FDA maximum tolerance), Apricot fruit $\mathrm{Pb}$ was below our $20 \mu \mathrm{g} \cdot \mathrm{kg}^{-1} \mathrm{fw}$ limit of detection ( $0.29 \%$ of the former FDA tolerance) even though soil $\mathrm{Pb}$ was as high as $730 \mathrm{mg} \cdot \mathrm{kg}^{-1}$. The arsenic concentration in 'Goldrich' leaves with arsenic phytotoxicity symptoms (1520 $\mu \mathrm{g} \cdot \mathrm{kg}^{-1} \mathrm{dw}$ ) was higher than in asymptomatic leaves $\left(150 \mu \mathrm{g} \cdot \mathrm{kg}^{-1} \mathrm{dw}\right)$. The 'Riland' leaves had an arsenic concentration of $1380 \mu \mathrm{g} \cdot \mathrm{kg}^{-1} \mathrm{dw}$ even though arsenic phytotoxicity symptoms were absent. These results suggest a difference in cultivar susceptibility to arsenic toxicity.

The arsenic concentration in the 'Gala' apple fruit also was positively related to $\mathrm{HCl}$ extractable soil arsenic (Fig. 2). Tree training system did not influence the relationship $(P=0.05)$. The highest fruit arsenic concentration was $68 \mu \mathrm{g} \cdot \mathrm{kg}^{-1} \mathrm{fw}(2.6 \%$ of the former FDA maximum tolerance). Sample SD for mean fruit arsenic concentration for an individual tree was $6 \mu \mathrm{g} \cdot \mathrm{kg}^{-1} \mathrm{fw}$. Apple fruit $\mathrm{Pb}$ was below our $24 \mu \mathrm{g} \cdot \mathrm{kg}^{-1}$ fw limit of detection $(0.34 \%$ of the former FDA tolerance), even though soil $\mathrm{Pb}$ was as high as $840 \mathrm{mg} \cdot \mathrm{kg}^{-1}$.

These results indicate that visual symptoms of arsenic phytotoxicity are species- and cultivar-specific. The data for apricot and apple suggest that arsenic accumulates in fruit at decreasing rates as soil arsenic increases, consistent with observations of fruits of other plant species (Woolson, 1983). The fruit arsenic concentrations were consistent with those reported for pome fruits grown on lead arsenate-contaminated soils elsewhere; however, the fruit $\mathrm{Pb}$ concentrations were substantially lower (Aten et al., 1980; Jones and Hatch, 1937; MacLean and Langille, 1981). These results are tentatively attributed to two factors. First, soil-derived $\mathrm{Pb}$ may accumulate in trees more slowly than does arsenic; hence, the concentrations of $\mathrm{Pb}$ and arsenic in the young trees of the current study may be in temporary "disequilibrium" with soil concentrations, unlike in the older trees examined in other studies. Second, the time that intervened between lead arsenate use and fruit analysis in the current study was 41 years, in contrast to "temporarily abandoned" in Jones and Hatch (1937) and 13 years in Aten et al. (1980), permitting more time for lead arsenate residues in the soil to transform to less soluble and, consequently, less phytoavailable $\mathrm{Pb}$ compounds, such as lead phosphates (Lindsay et al., 1989).

The results of the current study in Washington are consistent with those of similar studies elsewhere and support the EPA's conclusion that lead arsenate residues are not expected to be significant in tree fruit grown on lead arsenate-contaminated soils. The concentrated $\mathrm{HCl}$-extraction method was further validated as an appropriate soil testing procedure for estimating soil arsenic effects on deciduous fruit trees.

\section{Literature Cited}

Aten, C.F., J.B. Bourke, J.H. Martini, and J.C. Walton. 1980. Arsenic and lead in an orchard environment. Bul. Environ. Contam. Toxicol. 24:108-115.

Benson, N.R. 1976. Retardation of apple tree growth by soil arsenic residues. J. Amer. Soc. Hort. Sci. 101:251-253.

Benson, N.R., R.P. Covey, Jr., and W. Haglund. 1978. The apple replant problem in Washington state. J. Amer. Soc. Hort. Sci. 103:156-158.

Benson, N.R., C.G. Woodbridge, and R.D. Bartram. 1972. Nutrient disorders in tree fruits. Pacific Northwest Coop. Ext. Bul. 121, Pullman, Wash.

Dow, A.I., A.R. Halvorson, and R.B. Tukey. 1983. Special orchard soil tests. Coop. Ext. Bul. FG-28d; Washington State Univ., Pullman.

Hutton, M. 1987. Human health concerns of lead, mercury, cadmium and arsenic, p. 53-68. In: T.C. Hutchinson and K.M. Meema (eds.). Lead, mercury, cadmium and arsenic in the environment. Wiley, New York.

Jones, J.S. and M.B. Hatch. 1937. The significance of inorganic spray residue accumulations in orchard soils. Soil Sci. 44:37-63.

Lindsay, W.L., P.L. Vlek, and S.H. Chien. 1989. Phosphate minerals, D. 1089-1130. In: J.B. Dixon and S.B. Weed (eds.). Minerals in soil environments. 2nd ed. Soil Sci. Soc. Amer., Madison, Wis.

MacLean, K.S. and W.M. Langille. 1981. Arsenic in orchard and potato soils and plant tissue. Plant \& Soil 61:413-418.

Peryea, F.J. 1991a. Bioremediation of lead arsenate-contaminated soils. Project A-168-WASH Rpt., State of Washington Water Res. Ctr., Pullman.

Peryea, F.J. 1991b. Phosphate-induced release of arsenic from soils contaminated with lead arsenate. Soil Sci. Soc. Amer. J. 55:1301-1306.

Rolfe, G.L. 1973. Lead uptake by selected tree seedlings. J. Environ. Qual. 2:153-157.

U.S. Environmental Protection Agency. 1991a. Lead arsenate; revocation of tolerances. Congr. Fed. Register 56:13593-13594.

U.S. Environmental Protection Agency. 1991b. Calcium arsenate; revocation of tolerances. Congr. Fed. Register 56:13594-13595.

Veneman, P.L.M. 1985. Lead-arsenate pesticide residues in old orchards. Agron. Abstr. Amer. Soc. Agron., Madison, Wis. p. 32.

Veneman, P.L.M., S.M. Bodine, J.R. Murray, and J.H. Baker. 1982. Effectiveness of three rapid digestion methods to estimate total lead in orchard soils. Commun. Soil Sci. Plant Anal. 13:585-592.

Weisberg, S. 1985. Applied linear regression. Wiley, New York.

Woolson, E.A. 1973. Arsenic phytotoxicity and uptake by six vegetable crops. Weed Sci, 21:524527.

Woolson, E.A. 1983. Emissions, cycling and effects of arsenic in soil ecosystems, p. 51-139. In: B.A. Fowler (ed.). Biological and environmental effects of arsenic. Elsevier, New York. 